\title{
Second Yale Conference on Latin American Labor History
}

\author{
John D. French
}

Utah State University

On April 19-20, 1985, the Yale Council of Latin American Studies sponsored its second annual conference on current research in Latin American labor history. A successful meeting in 1984, dealing with the post-World-War II period, had focused on "Populism and the Working Class: Approaches to the Study of Latin American Labor." While lacking a single thematic focus, the 1985 conference examined aspects of working class life and politics between 1900 and 1930.

In "The Politics of Anti-Politics: Anarchism in the Sao Paulo Labor Movement, 1900-1935," John French tied the predominant form of workingclass radicalism in Sao Paulo to the diversity of workers' conditions, experiences, and behavior in the early twentieth century. The decline of anarchist influence, it was argued, involved a growing acceptance of indirect actiontied to the needs of the industrial working class-and a decisive shift in the state's role in labor relations after 1930; thus ending the prevalent practice of "revolutionary unionism" merging the economic and political struggles of radical labor. In ensuing comments from Peter Blanchard (Toronto), Paulo Sergio Pinheiro (UNICAMP, Brazil), David Montgomery (Yale), and others, debate examined the logic of the shift in labor strategy that resulted in the decline of the anarchist option.

The University of Miami's Steve Stein presented a paper derived from an ambitious current project that is reconstructing working class life in Lima, Peru before 1930. "Don Pedro Frias and the Creation of Historical Documents: An Example of Oral History" argued for the special utility of oral history for the social historian as well as its real and imagined limitations. Concrete examples, such as workers' racial prejudices, were used to demonstrate the strength that the essentially subjective nature of oral history provided the historian, when properly used, in understanding both daily life and specific historical events. Warning against illusions of representativeness, Stein illustrated his points with a small excerpt from an interview with an older Lima textile worker, at the same time a union activist, soccer fanatic, and fol-

International Labor and Working Class History

No. 28, Fall 1985, pp. 94-95

(C) 1985 by the Board of Trustees of the University of Illinois 
lower of the populist APRISTA party. The ensuing discussion revealed the prevalence of oral history among those doing labor history research and the felt need for more such methodological reflection.

Daniel James (Yale) read a paper on "Immigrants and Industrial Politics: The Case of the Argentine Communist Party, 1917-30," which focused on the interaction between Communist worker militants and the working class during the twenties, a period of union disarray and worker demoralization. Despite the PCA's formal objectives, their industrial practice in the twenties remained decisively shaped by the predominant mix of small and large scale industry, the continued anarchist and syndicalist-influenced political culture of the milieux of labor militants, and the impact of large-scale immigration. Posing questions as to the nature of immigrant consciousness, James examined the PCA's dilemma and tied this social context to the Communists' relatively greater success in neighborhood over factory organization.

The James piece was followed by an examination of the international dimension of Latin American Communism by Konrad Stenzel. "Revolutionary Ignorance and Pragmatism of the Left: A Populist Re-interpretation of the Communist International and National Communist Parties in Latin America, 1928-1935" argued that the rigid application of established European chronologies had led to a misunderstanding of the peculiarities of the Latin American case, which was shaped by a breakdown of oligarchic hegemony and the absence of mass social democratic allegiances. Thus scholars have missed an innovative and not entirely ineffectual Communist effort to establish a strategy for Latin America that could be called "populism with a revolutionary perspective."

The conference ended with a paper by Alberto Vourvoulias that grappled with the protean manifestations of Latin American populism. His "Visions of the Good Brazil: Getulio Vargas and Populist Discourse"' on the elastic nature of populist political rhetoric received incisive comments from Brazilian political scientist Maria do Carmo Campello de Souza. After two days of fruitful discussion, the participants from the United States, Canada, and Brazil departed with the knowledge that new approaches could in fact be made to such older subjects as anarchism and communism. There was also hope that in future conferences, with increased international participation, the issues of working-class culture and the interaction of gender, family, and class would be dealt with in their Latin American context. 